\title{
Editorial
}

\section{Re-Emergence of Chikungunya Virus: Completed Setup and the Danger of Imminent Invasion}

Chikungunya is a relatively rare form of viral fever caused by an alpha virus that is transmitted by bites of the Aedes aegypti mosquitoes. ${ }^{1}$ The name is derived from the word "Makonde" meaning "that which bends up" in reference to the stooped posture developed as a result of the arthritic symptoms of the disease. Humans are thought to be the major source, or "reservoir" of the Chikungunya virus for mosquitoes. ${ }^{1}$ Chikungunya usually starts suddenly with fever, chills, headache, nausea, vomiting, joint pain, and rash. Frequently, the infection causes no symptoms, especially in children. While recovery from Chikungunya is the expected outcome, it may take up to a year or more for complete recovery. Persistent joint pain may require pain medication and longterm anti-inflammatory therapy. ${ }^{2}$

Chikungunya infection can be diagnosed by serological tests. Since the symptoms of Chikungunya are similar to Dengue fever, it is important to be medically evaluated and have blood tests done, especially in areas where both diseases are present. $^{2}$

Chikungunya is a specifically tropical disease, but it is geographically restricted and outbreaks are relatively uncommon. It is only occasionally observed in travellers and military personnel. ${ }^{2}$ The disease was first described by Marion Robinson ${ }^{3}$ and WHR Lumsden ${ }^{4}$ in 1955, following an outbreak on the Makonde Plateau, along the border between Tanganyika and Mozambique in 1952. The first outbreak in India was in 1963 in Calcutta. An outbreak of Chikungunya was also reported from Port Klang in Malaysia in 1999 affecting 27 people. $^{2}$

In recent years, countries in the South-East Asia Region have been severely affected by the outbreaks of Chikungunya fever. India was hit in 2006 after a quiescence of 32 years. Indonesia, Maldives, and Sri Lanka have also been swept by this emerging infection. Various factors that have been incriminated for resurgence of Chikungunya include mutation of the virus, absence of herd immunity, lack of efficient vector control activities, globalization and emergence of Aedes albopictus, in addition to Aedes aegyptii as an efficient vector for Chikungunya virus. ${ }^{5}$

Since the beginning of 2006, the crippling mosquito-borne disease has shown an explosive appearance in nations in the Indian Ocean area. More than 266,000 people had been infected along the French Reunion islands with 200 deaths. ${ }^{6}$ It had invaded the islands of Seychelles, Mauritius, and Mayetta (French). Subsequently, the disease appeared in India, China and European countries. The World Health Organization is presently coordinating the measures to assist in fighting the epidemic. ${ }^{7}$

Chikungunya virus infection recently re-emerged in Malaysia after 7 years of non-detection. ${ }^{8}$ In December, 2006, over 60,000 cases were detected in Sri Lanka, with over 80 deaths. ${ }^{2}$ In October 2006, more than a dozen cases of Chikungunya were reported in Pakistan. ${ }^{2}$ In Indonesia, there have been over 1200 suspected cases reported in the year 2007.5 The outbreak in Maldives started in December 2006 and lasted for three months. A total of 10,831 suspected cases ( $4.5 \%$ of the population) were reported in Maldives.

In 2006, more than 1.38 million cases of Chikungunya were reported in India. During 2007, a total of 56,365 suspected cases have been reported from 14 Indian states and Union Territories. The state of Kerala alone accounts for $42.7 \%$ of the cases, claiming more than 50 lives. ${ }^{5}$ The states of West Bengal and Lakshyadweep recorded higher number of cases in 2007 as compared to that of 2006. Scores of people suffering with this crippling fever have been reported from North 24- Pargana district of West Bengal. ${ }^{9}$

The reasons for the re-emergence of Chikungunya on the Indian subcontinent, and for its unprecedented incidence rate in the Indian Ocean region, are unclear. Possible explanations include increased tourism, Chikungunya virus introduction into a naive population, and viral mutation. Chikungunya 
fever is reported in India after 32 years. Immunoglobulin M antibodies and virus isolation confirmed the cause. Phylogenic analysis showed that all earlier isolates were Asian genotype, whereas the current isolates were African genotype. ${ }^{9}$

In 2006 in Bangladesh, two groups of scientists from Institute for Epidemiology Disease Control and Research (IEDCR) and International Center for Diarrhoeal Disease Research, Bangladesh (ICDDR,B) found no evidence of Chikungunya virus in 175 blood samples collected from febrile patients. ${ }^{10}$

Chikungunya has established endemicity in several parts of South-East Asia region. Ongoing outbreak of Chikungunya in India especially in West Bengal, ${ }^{11}$ which is adjacent to Bangladesh, imposes a potential threat of Chikungunya epidemic in this country. The socio-economic factors and public health inadequacies that facilitated the spread of this infection in Indian population continue to exist in Bangladesh as well. Entrenched Aedes aegypti in densely populated urban areas, increasing number of marginalized floating population, overcrowding, cross-border travelling have increased the risk of introduction of this little known virus. There is an urgent need to strengthen national surveillance and develop response capacity through multisectoral approach and active participation of the communities to prevent and contain this emerging infectious disease. Otherwise similar chaotic situation like early days of unabated Dengue invasion in Dhaka City may have to be faced.

Osul Ahmed Chowdhury Professor of Microbiology and Vice-Principal Sylhet MAG Osmani Medical College Sylhet-3100

\section{Muhammad Shamsher Ahmed}

Assistant Professor Department of Microbiology Sylhet MAG Osmani Medical College Sylhet-3100

\section{References}

1. Anonymous. Chikungunya-History. Web page, retrieved from "http//www.Medindin.net/patients/patientsinfo/chikungunyaHistory.htm" (accessed on 20.10.2007)

2. Anonymous. Chikungunya. Web page, retrieved from "http://en.wikipedia.org/wiki/Chikungunya" (accessed on 20.10.2007)

3. Marion R. An epidemic of virus disease in Southern province, Tanganyika Territory, in 1952-53; I. Clinical features. Trans Royal Society Trop Med Hyg 1955; 49 (1): 28-32.

4. Lumsden WHR. An epidemic of virus disease in Southern Province, Tanganyika Territory, in 1952-53; II. General description and epidemiology. Trans Royal Society Trop Med Hyg 1955; 49 (1): 33-57.

5. World Health Organization. Chikungunya in South-East Asia. Web page, accessed on date: 20.10.2007 at "http://www.searo.who.int/EN/Section10/Section.htm"

6. Ligon BL. Re-emergence of an unusual disease: the Chikungunya epidemic. Semin Pediatr Infect Dis 2006; 17 (2): 99-104.

7. Pialoux G, Gaüzère BA, Jauréguiberry S, Strobel M. Chikungunya, an epidemic arbovirosis. Lancet Infect Dis 2007; 7 (5): 319-327.

8. AbuBakar S, Sam IC, Wong PF, MatRahim N, Hooi PS, Roslan N. Re-emergence of endemic Chikungunya, Malaysia. Emerg Infect Dis 2007; 13 (1):147-149.

9. Yergolkar PN, Tandale BV, Arankalle VA, et al. Chikungunya outbreaks caused by African genotype, India. Emerg Infect Dis 2006; 12 (10):1580-1583.

10. International Center for Diarrhoeal Diseases in Bangladesh (ICDDR,B). No evidence of Chikungunya virus in Dhaka, Bangladesh. Health Sci Bull 2007; 5 (1): 1-4.

11. Anonymous. The threat of Chikungunya. Website: "http://www.medindia.net/news/West-Bengal-in-the-Threat-ofChikungunya.htm" (accessed on 20.10.2007) 